\title{
In coelestibus: The Spiritual Combat of Onésime Lacouture, S.J.
}

\author{
Jack Lee Downey \\ La Salle University \\ downeyj@lasalle.edu
}

\begin{abstract}
This paper examines the history of Lacouturisme, a retreat movement founded by the Jesuit retreat leader Onésime Lacouture (d.1951), in Québec and the United States. Based on a redaction of the Ignatian Exercises, Lacouture's ascetic theology was especially popular among Canadien seminarians, until it was subject to formal censurebased both on questions of orthodoxy and its apologists' pugilistic iconoclasm. "The retreat" migrated southward, largely under the stewardship of Pittsburgh diocesan priest John Hugo (1911-85), and became deeply critical in the spiritual formation of Dorothy Day. Lacouturisme signaled an upswell of enduring Christian debates, such as the relationship between nature and grace, the boundaries of orthodoxy, and the call to moral perfection. Although the retreat's theology counselled a measure of social withdrawal, it became spiritual fodder for the Catholic Worker Movement's radical personalism.
\end{abstract}

\section{Keywords}

Catholic Worker - Québec - American Catholicism - asceticism - Dorothy Day retreat

It was probably about the time that Onésime Lacouture, S.J. (1881-1951) started to publicly denounce his religious superiors as emissaries of Satan that the countdown to his formal censure and the withdrawal of clerical faculties began in earnest. In 1941, Lacouture had been a fiery up-and-coming revivalist who preached a return to fundamental Catholic spirituality as a bulwark of the resistance to creeping secular materialism. He was a mystical and ascetic

(C) JACK LEE DOWNEY, 2018 | DOI:10.1163/22141332-00504004

This is an open access article distributed under the terms of the prevailing CC-BY-NC license at the time of publication. 
iconoclast who translated his own experiences into a program of contemplative retreat, based on the Exercises of St. Ignatius of Loyola (c.1491-1556), which he recontextualized for the needs of contemporary spiritual combat. Massively popular among Canadien seminarians and religious, Lacouture's "extreme" approach-an unrelenting critique of mainstream Catholicism's capitulation to modernity-drew exacting scrutiny, which only escalated as Lacouture responded violently to superiors' theological inquiries. This led to his eventual removal from active ministry and exile - but not before he managed to acquire a following of pilgrim clergy from the United States. These dévots shepherded the retreat southward, eventually intersecting with Dorothy Day and the Catholic Worker Movement, whose radical Christian anarchism proved fertile grounds for their evolutionary mutation of Lacouture's work. The story of Lacouturisme is one of cosmic warfare, whose protagonists mounted an assault on Catholic tepidity, which they viewed as the terrestrial manifestation of the demonic. Insofar as they subscribed to Cyprian of Carthage's classical fortress dictum that extra Ecclesiam nulla salus, their definition of "church" was substantially more exclusive than James Joyce's "here comes everybody" —or even Leonard Feeney (1897-1978).

One of the mysteries of Onésime Lacouture-variously condemned as a Jansenist, proto-Calvinist, and Pelagian-was his extreme influence on the Catholic Worker, a bedrock of the twentieth-century Catholic Left in the United States, which made a reputation for welcoming all comers to their "houses of hospitality" during the Great Depression in the 1930s. Lacouture saw his own mission for Christian renewal as messianic — of most critical importance given the prevalence of nominally Christian "paganism" among fellow Catholics, whom he viewed as largely unwitting apostates (a kind of inversion of Karl Rahner's [1904-84] "anonymous Christian"). ${ }^{1}$ While Day did not share Lacouture's predilection for interpreting ecclesiastical scrutiny as evidence of satanic conspiracies, she did share some of his binary cosmic cartography, and observed demonic machinations behind the contemporary social injustices of poverty, militarism, and socialization into the culture of domination.

Onésime Lacouture's unshakable belief in his prophetic mission was rooted in a sense that he lived in degenerate times, which saw a quickening of malevolent forces laying siege against the church. Along with the Canadien nationalist political theology of Lionel Groulx, Lacouture's supernaturalism witnessed the spiritual combat in literalist terms, and the souls of the faithful as under attack by demonic forces-not just in the advance of Anglo-Protestantism from

1 Karl Rahner, Karl Rahner in Dialogue: Conversations and Interviews, 1965-1982, ed. Paul Imhof et al. (New York: Crossroad, 1986), 135. 
without upon "indigenous" Catholic lands in Québec, but also the encroachment of "paganism" within the very soul of the church. Lacouture's demonology was not abstract, but imminent - manifested in interior movements of the soul, but also in structural developments like cultural assimilation to modern secularism. Furthermore, as Lacouture's preaching elicited increasingly severe critiques, he witnessed the work of the Evil One operating through his religious superiors, to repress his divinely sanctioned "return to the Gospel." Lacouture's supernatural vocation was matched by his ecclesiastically powerful antagonists, in whose attempts to quell his insurrection Lacouture witnessed traces of a more cosmic, timeless conflict.

\section{Origins of Lacouturisme}

Little by little a light dawned in my soul, and I began to see the divine side of human affairs. I understood that the evil was only in my twisted pagan spirit which judged everything solely from the point of view of this world, while God does all in view of the next. ${ }^{3}$

Onésime Lacouture's life was an exercise in border-crossing and cultural hybridity. He was born as the second youngest of twenty-one into a revanche $d u$ berceau Québécois family on April 13, 1881, some forty-five miles northeast of Montréal. ${ }^{4}$ When Onésime was six years old, the entire clan hopped aboard the francophone exodus to New England-first to Woonsocket, Rhode Island (an enclave of Canadien refugee mysticism - including the stigmatic Marie Rose Ferron $[1902-36])$, and one year later to what is now Wayland, Massachusetts. ${ }^{5}$ Following his high school graduation in 1900, Lacouture returned to Québec to enroll in the Collège de l'Assomption, where he was introduced to the Society of Jesus. The Jesuit reputation for scholastic excellence and missionary frontier dramatics exerted an irresistible pull on the budding seminarian. Following his philosophy studies at St. Andrew on the Hudson in Poughkeepsie, Lacouture's

2 This is chronicled in some painstaking detail in my book: Jack Lee Downey, The Bread of the Strong: Lacouturisme and the Folly of the Cross, 1910-1985 (New York: Fordham University Press, 2015).

3 Onésime Lacouture, Mon séjour en Alaska (1910-1913), trans. Jack Lee Downey (Québec: Éditions Scivias, 1998), 4-5.

4 Lacouture, Mon séjour en Alaska, 12. See Karl Strauch, La thème de la "folie de la Croix" dans l'oeuvre du Père Onésime Lacouture [1881-1951] (Montréal: Cahiers Scivias, 1998), 22.

5 Paula M. Kane, "She offered herself up': The Victim Soul and Victim Spirituality in Catholicism," Church History 71, no. 1 (2002): 80-119, here 114. Lacouture, Mon séjour en Alaska, 13. 
interest was piqued at the prospect of obtaining a teaching post at the recently opened Sophia University in Tokyo. However, his application was rejected by his provincial, who instead saw it fit to send him to the remote, frigid wilderness of the Alaskan tundra, which he would come to call his "White Desert." Lacouture resiliently and quickly embraced his harsh assignment, modeling himself after a perennial Jesuit favorite, the itinerant Saint Francis Xavier $\left(1506-5^{2}\right)$.

In early July of 1910, Lacouture awoke with a start, choking on the thick, black smoke that flooded into the cabin car as his train sped westward through the Canadian boreal forest. This marked an epic year for North American wildfires characterized by uncommon aridity levels that combined with the incendiary hazards of coal-powered locomotives. As many as three thousand wildfires erupted throughout Idaho and Montana - the largest on a scale of three million acres, which blocked the sun as far north as Saskatoon. However, Lacouture's mind was not on forestry or the unintended ecological consequences of modern industrialization. ${ }^{6}$ As he gasped for air and tossed about in his sweatsoaked pajamas, Lacouture's initial presumption was that he had died and gone to purgatory. Although he quickly came to his senses, the episode nevertheless remained instructive to his missionary sojourn into the wilderness of the Alaskan tundra; it set the desolate framework for a series of mystical revelations that would forge him into a thaumaturgic evangelist and prophetic gadfly. He would come to remember this episode acutely: "God wanted me to pass from one extreme to another: before putting me on ice, he made me pass through the fire!"7 The Alaskan landscape that he would soon come to call "The Desert of Snow" played a critical role in Lacouture's interior spiritual combat, the natural world itself performing a communicative — almost sacramentalrole in sharpening his mystical acumen and preparing him for his true vocation as a barnstorming revivalist.

Lacouture's time in Alaska would prove to be a site more so for his own conversion rather than the harvest of "pagan" souls. The stark, frigid landscape seemed to mirror his overwhelming waves of interior desolation and self-doubt. And although he admired the noble simplicity of the local community, he found his mundane daily tasks to be mindnumbingly trivial. As it so happened, because of his late arrival at Holy Cross Lacouture had missed the scheduled annual retreat and subsequently received permission to partake in the Ignatian Exercises alone. Although he would return to his normal

6 Timothy Morton, Hyperobjects: Philosophy and Ecology after the End of the World (Minneapolis: University of Minnesota Press, 2013).

7 Lacouture, Mon séjour en Alaska, 8. 
residence in the evenings, Lacouture spent days isolated in the forest wilderness, uninterrupted by work or social obligations. Armed with high supernatural expectations and a copy of the Exercises, he was invigorated by these days spent in prayer and meditation under the open sky, or huddled in some natural shelter or snowdrift along the banks of a nearby lake. The conditions were intimidating, and Lacouture suspected that forces conspired to derail his progress in prayer. Here Lacouture came to "know many things," which he would later interpret as analogues to St. Ignatius's experiences at Manresa: ${ }^{8}$

I felt like I was dying to this world only to be revived in another. Something told me that I was beginning a new existence: I had been living more or less on the moon, by absorbing the doctrine of Jesus Christ intellectually: I had studied the spiritual life, I had heard it and knew all the great lines; I would live them now, sacrificing creatures and myself. If God forced me to experience something of Tabor, it was because my Calvary was not far! ${ }^{9}$

Lacouture anticipated that his greatest challenge would be suffering through the austere conditions of the Alaskan wilderness and the loneliness of his isolation from civilization. He had arrived with dreams of saving souls but it was the solitude of the desert that both precipitated his psycho-spiritual meltdown, and served as the communicative landscape for his resuscitation. He suddenly found himself living on the supernatural plane, which he had previously professed belief in on a conceptual level, but had yet to experience directly; a true point of genesis for his future vocation.

Composed as an extended letter to his mother, Lacouture's memoir of this chapter of his life re-imagines it as a precursor to his real work as another type of missionary; as a remote place of transfiguration within his messianic imagination. Lacouture came to believe that it was not the local Deg Xit'an who needed converting so much as the spiritually tepid Christians among whom he might himself have been considered until just recently. He emerged from the wild with a divine commission to re-enter society and share his spiritual gifts. After just a year, Lacouture would hitch a ride back to the mainland, to complete his pre-ordination studies, before being liberated to pursue his dreams of becoming a retreat master. In his recollections, Alaska is figured as both a staging ground for, and conduit of, ascetic-mystical transformation. And although he persisted in fretting about the fate of their eternal souls, the indigenous

8 Ibid., $87 \mathrm{ff}$.

9 Ibid., 23-24. 
community at Holy Cross played only a peripheral role in his narrative;as if they were merely part of the sublime scenery, they nearly go unacknowledged following his retreat experience. ${ }^{10}$ Lacouture's arctic transfiguration was foundational - both in the development of his spiritual rigor, and in his antiintellectual distaste for institutional mediation and mainstream tepidity. This marked a pivot point in Lacouture's life trajectory, diverting him from a more conventional life as an academic, parish priest, or socially conscious public intellectual towards a vocation as a preacher. ${ }^{11}$ His practical experience of God now superseded the abstraction and theory which consumed his formation studies, and — he believed—-persisted among his Jesuit brethren. ${ }^{12}$

Historian Peter Brown has described the desert as a fantastical landscape; an "ecological frontier" set apart from the world where early Christian spiritual warriors both escaped the mundane distractions of the city, and also sought out the demonic; a stage for the spiritual combat. ${ }^{13}$ The biblical trope of sojourning Israelites provided both a metaphorical identity for Christian conceptions of estrangement from the world, as well as a model for prayerful withdrawal paradigmatically beatified by Christ. ${ }^{14}$ Far from simply being a fertile object of fantasy for overactive imaginations enthralled by the supernatural, the desert became coded as both a physical place and an aesthetic way of being. It was conceived as a conceptual space based on contrast; defined both by the ecological and the spiritual, it was characterized as a "counter-world" and ultimate "Other."15

Bracketing interesting conversations about the various hyphenated "Catholic Modernisms," Lacouture envisioned himself a spiritual primitivist. ${ }^{16}$

$10 \quad$ Ibid., $98-99$.

11 Ibid., 131.

12 Ibid., 121.

13 Peter Brown, The Body \& Society: Men, Women, \& Sexual Renunciation in Early Christianity (New York: Columbia University Press, 1988), 216. The myth of the desert was one of the most abiding creations of late antiquity. It was, above all, a myth of liberating precision. It delimited the towering presence of "the world," from which the Christian must be set free, by emphasizing a clear ecological frontier. It identified the process of disengagement from the world with a move from one ecological zone to another, from the settled land of Egypt to the desert. It was a brutally clear boundary, already heavy with immemorial associations.

14 Ingvild Sælid Gilhus, “The mountain, a desert place': Spatial Categories and Mythical Landscapes in the Secret Book of John," in Wilderness and Mythology in Religion, ed. Laura Feldt (Oakville, ст: Equinox Publishing, 2012), 103.

15 Brown, Body \& Society, 217.

16 See also Bruno Latour, We Have Never Been Modern, trans. Catherine Porter (Cambridge, MA: Harvard University Press, 1993); Stephen Schloesser, Jazz Age Catholicism: Mystic Modernism in Postwar Paris, 1919-1933 (Toronto: University of Toronto Press, 2005); Robert 
Although he lacked the graphic flair of someone like the twelfth-century apocalyptic visionary Joachim of Fiore (1135-1202), Lacouture interpreted his own life as a recapitulation of ancient Christian narratives. Both his depictions of his formative experiences in Alaska, and his later attempts to build a "desert experience" within the context of his closed retreats (which were often hosted at farms and therefore not considered a desert in the literal sense) drew upon a long tradition of Christian appropriation of wilderness imagery as a code for paradigms of ascetic withdrawal and mystical illumination. "The Desert" became a metaphorical space; a state of mind with all the transformative effects and without any of the actual physical danger. Through this state of mind, he enacted a secondary—and in a sense neoliberal—form of colonial visioning: that of wilderness as a site of personal transformation and spiritual combat, rather than of imperial conquest.

Lacouture's apocalyptic imagination was not entirely exceptional within the Canadien cultural climate. In the wake of the apostasy of the French Revolution, expatriate colonists in what is now Québec and the Maritimes depicted themselves as sojourning Israelites, a remnant. This itinerant group identity rapidly morphed into a robust nativism and extreme collective amnesia regarding their migrant status. They drew creative inspiration from the Book of Exodus and an identification with Israel as well as recapitulated the Babylonian Captivity — framing what was formerly known as "Lower Canada" as an indigenously Roman Catholic land, toiling under the bondage of Anglo-Protestant oppression from without. ${ }^{17}$ Industrialization and urbanization increasingly fractured the population of Lower Canada, challenging ultramontane stability during the late nineteenth century ${ }^{18}$ Les Canadiens faced a mounting concern over the corrosive threats of cultural dilution and Anglo-assimilation. This selfconsciously reactionary mentalité that undergirded the collective lifeworld of post-Confederation Québec conditioned the soil from which Lacouturisme emerged.

A. Orsi, "Everyday Religion and the Contemporary World: The Un-Modern, or What Was Supposed to Have Disappeared but Did Not," in Ordinary Lives and Grand Schemes: An Anthropology of Everyday Religion, ed. Samuli Schielke and Liza Debevec (New York: Berghahn Books, 2012); Paula Kane, Sister Thorn and Catholic Mysticism in Modern America (Chapel Hill: University of North Carolina Press, 2013).

17 Francis Parkman, The Old Régime in Canada, 2 vols. (Boston: Little, Brown and Company, 1902), 2:203-4.

18 Terence J. Fay, A History of Canadian Catholics: Gallicanism, Romanism, and Canadianism (Montréal: McGill-Queen's University Press, 2002), 81. See also Jay Dolan, The American Catholic Experience: A History from Colonial Times to the Present (Garden City, NY: Doubleday, 1985), 436; Jacques Lacoursière and Robin Philpot, A People's History of Quebec (Montréal: Baraka Books, 2009), 121. 


\section{Conflict and Exile}

For several years now we have been witnessing in the Province a struggle which is as interesting as it is one-sided. Two tendencies are in conflict among Christians. Many do not realize the gravity of this conflict which is, in reality, a struggle "in coelestibus," between the good and the bad angels. Because of the immense number of Christians who are gently slipping in the direction of paganism and damnation, through the appeal of comfort, of well-being and of "legitimate" pleasures, certain priests have conceived the idea of reaction against this state of affairs and have begun to preach again the Sermon on the Mount. ${ }^{19}$

Although he essentially stowed away on a ship heading back to civilization to avoid an additional year at the mission, Lacouture almost instantaneously integrated his Alaskan sojourn into a vocational imperative to renew primitive, "authentic" Christianity. The young seminarian who now dubbed himself "God's scalpel" seems to have suffered through what remained of his theological studies, and was ordained to the priesthood in 1916. After a stint as a military chaplain in Europe and India, Lacouture eventually made his way back to Québec, and began his ministry as a semi-itinerant circuit preacher. Lacouture's ten-day silent retreats where essentially a redaction of the Ignatian Exercises, tailored to conform to his mystical experiences in Alaska. The retreats were humbly received at the beginning, with a grand total of four participants the first time around in 1931. Nonetheless, his client base began to swell—his own statistics indicate that his retreat participants numbered close to three thousand $\left(2,93^{2}\right)$, with many returning for repeat performances $(5,400$ total).

Lacouture's theology located the morality of discrete actions squarely in the individual's motivation, hence his antipathy to any discussion whatsoever of things in se. As rosy as the doctrine of samples sounded, Lacouture cautioned of the practical stumbling blocks that are inherent to lived reality-our fallibility and natural self-absorption. Lacouture deemed it virtually irrelevant that particular actions might be considered harmless in and of themselves. He believed our interior disposition and underlying existential motivations were determining factors to moral judgment, thus our motivations render all temporal pleasures potentially hazardous. As a student of Augustinianisms, he located the root of moral failings in concupiscence, which infects human motivations and deforms all actions in respect to their proper order in the supernatural

19 D. L.Crenier, “Grace and Nature," Bulletin de Saint Benoît (1941) (Fonds Onésime Lacouture / Anselme Longpré, Bibliothèque et Archives Nationales du Québec [P9/D4]). 
scheme of things: "Concupiscence is the sensible attraction to pleasures. It is the great underlying source of our natural motives, because it easily infects all our approaches and actions, so that we revel in the creatures we encounter."20

Inherited original sin prescribes that we are born into a state of temporal attachment. It is only divine gift that empowers us to rise out of the muck, so to speak. While radical detachment, apatheia, may be the final goal of the ascetic, most practitioners take baby steps. Although tedious, it is more practical to instruct discipline and restrict participation in specific activities, thereby transforming oneself on a more existential level, which will effectively extend to all activities. External ascetic practices are valuable precisely because they facilitate interior conversion. ${ }^{21}$

The experience of suffering is a necessary aspect of the renunciant's spiritual combat. It represents a kind of growing pain as the soul tears itself fromand is torn from-its habitual attachments. ${ }^{22}$ As the Christian soul begins on the road to perfection, it needs to recondition its desire, initially through deprivation. This is experienced as suffering and persists in varied levels as the vigilant soul progresses in holiness. However, this is only one form of suffering that Lacouture touched upon throughout his retreat program. Drawing inspiration from the letters of St. Paul, Lacouture delineates three causes of the suffering that the pious soul should expect to endure as it becomes increasingly sanctified: sins, the imitation of Christ, and participation in the divine life. ${ }^{23}$ While in many ways suffering is a side effect of the soul's ongoing conversion, it is also the spiritual flesh wound doled out by malevolent forces whose endurance serves a redemptive function and further speeds progress toward sanctification: ${ }^{24}$

According to Saint Paul, God truly slaughters us! For the body, He sends all sorts of illnesses and infirmities; by the deprivation of poverty, and the avarice and ambition of others. Those big businesses that destroy smaller

$20 \quad$ Crenier, "Grace and Nature," 39.

21 Richard Valantasis, "A Theory of Social Function of Asceticism," in Asceticism, ed. Vincent L. Wimbush and Richard Valantasis (New York: Oxford University Press, 1998), 548. See also, Richard Schechner, "Magnitude of Performance," in The Anthropology of Experience, ed. Victor W. Turner and Edward M. Bruner (Urbana: University of Illinois Press, 1986), 345 .

22 Lacouture, Mes retraites, 419.

23 Lacouture, Mes retraites, 264; Heb. 12:1-8.

24 See Adam Kotsko's analysis of evil in the "Deuteronomistic" and "prophetic" paradigms of evil in the Hebrew Bible. Adam Kotsko, The Prince of This World (Stanford, CA: Stanford University Press, 2016). 
ones! Those giant industries that exploit their employees! Like the governments who oppress the world through excessive abuses and debilitating taxes for the common people! [...]. Then plagues ruin the earth: fire, flood, earthquakes, drought, torrential downpours, frost, etc. ${ }^{25}$

Natural disasters and "bad luck" present one with an opportunity for detachment and thus to imitate Christ's activity; to participate in the divine life. He even went so far as to imply that certain instances of this form of suffering may actually be sent by God in order to purge and perfect the soul. Among other forms of suffering that are inevitable for the Christian progressing in holiness are those imposed by antagonism from loved ones, those we leave behind in "the world," and even from religious superiors (with which Lacouture grew very familiar). The maximalist Christian must prepare to be mocked, rebuked, attacked, as well as verbally, physically, and psychologically persecuted, as Jesus was. The antidote for suffering is detachment, which is achieved through the practice of self-mortification. In Lacouture's system, again echoing John of the Cross's (1542-91) "dark night of the spirit," persecution is itself a sign of progress, and the soul may take consolation in that assurance during times of anxiety and doubt. In fact, Lacouture goes one step further by alleging that one cannot achieve true holiness without being hated, reviled, and oppressed by those who uphold pagan hegemony and Christian mediocrity—a claim that has extreme countercultural implications if taken to its logical conclusion. The drama that plays out in the renunciant's interior life-her struggle against her own attachments - is simultaneously paralleled on the supernatural plane in the battle for souls.

Although Lacouture's retreat was rooted in the Exercises, in practice it was more of a creative abridgement. He composed extensive retreat outlines for his three "series" - a contraction of Ignatius's four "weeks" - but never managed to complete the full sequence of conferences throughout any of his retreats. In fact, he only very rarely moved beyond his "première série" - the meditations on sin and hell. ${ }^{26}$ Retrospectively considering this coupled with Lacouture's avowed anti-assimilationist contrarianism and rumors of rigid ascetic content, it is no surprise that the retreat drew attention from higher up the ecclesiastical food chain. However, Lacouture's providential sense of mission rendered him constitutionally incapable of abiding even hints of criticism, which caused him to react violently to even modest theological inquiries. Lacouture's

25 Lacouture, Mes retraites, 264, 266.

26 Anselme Longpré, Un mouvement spirituel au Québec (1931-1962): Un retour à l'Évangile (Montréal: Fides, 1975), 25-26. 
objectives regarding the reception of his teachings alternated between poles; he desperately attempted to spread his "doctrine" throughout the ranks of the Canadian clergy and vowed religious would-be agents who would disseminate his revivalist theology throughout the province, while also persistently longing for the sanction and approval of his superiors. Even in his twilight years, he continued to seek vindication from Norbert de Boynes (1870-1954), the interim successor to Włodzimierz Ledóchowski (1866-1942) as Jesuit superior general - to no avail. It seems as though Lacouture both yearned for mainstream acceptance and reveled in its withholding. Moreover, as he was increasingly removed from public (and even private) ministry, and had his access to supporters suffocated, Lacouture found vindication in aligning his experiences of persecution with those of the great martyrs of Christian tradition, and of course, along with their archetype, Jesus Christ. ${ }^{27}$

\section{Demonology in Lacouturite Thought}

Saint Michael's team gives itself completely to God; Lucifer's is completely self-absorbed [...]. How Christians imitate them! They act like true pagans, solely according to their own judgment and their own will, saying: "this is not evil in se." Lucifer is their patron, and where are the priests to challenge them?28

One major feature of Lacouture's retreat notes and later polemics that may seem bizarre to modern readers - as perhaps they did to some contemporaries-is his frequent and candid references to demons and their role in derailing spiritual progress. Lacouture's worldview was immanently supernatural. His vision of angels and demons was not abstract; he believed that they were active subjects who inhabited the world and initiated war with one another. Lacouture's cosmology was teeming with supernatural enemies who prey on human weakness and use the allure of "paganism" to coerce vulnerable Christians.

27 Candida R. Moss, The Myth of Persecution: How Early Christians Invented a Story of Martyrdom (New York: HarperOne, 2013). In this work, Moss shows that, although persecution was not as pervasive as rendered in Christian collective memory, it has nevertheless served a critical formative role. Lacouturisme both participated in and recapitulated this myth-making enterprise; Lacouture's own "persecution" was similarly formative for Lacouturites, and gained vitality through its perceived resonance with Christ's archetypal martyrdom.

28 Lacouture, Mes retraites, $136-37$. 
In his study of demonology and early monasticism in fourth- and fifthcentury Egypt, David Brakke highlights the monk's role in replacing the martyr by amplifying and supercharging his perception of assaults on the church. As anticipation of the imminent end of the world waned, along with the "prospect of actual martyrdom," steadfast fortitude in the face of violent persecution was internalized and reconceptualized through an emphasis on the moral life and cultivation of a resistance to temptation. ${ }^{29}$ In this context, desert ascetics came to be viewed-in no small part thanks to Saint Athanasius's (296-373) then voguish Life of St. Antony - as God's infantry; spiritual warriors who vanquished demons through the interior combat. ${ }^{30}$ On the micro level, the monk's ability to withstand an onslaught of demons in the desert-which he ventured out into the desert specifically to confront-was a personal victory. The monk himself grew in holiness, being spiritually fortified throughout the process. From a macro perspective, however, this personal victory had wide-ranging fallout on ecclesiastical and supernatural levels. Although monasticism has been criticized as representing an antisocial, navel-gazing impulse, it came to be viewed as a critical service to both God and the larger community of believers. The cultivation of individual holiness served a vital and profound communal function.

In Lacouture's schema, the demons' primary role is to sabotage the Christian soul's progress toward perfection. ${ }^{31}$ It does this using the full range of its considerable resources including the ability to manipulate one's affections or confront one through more direct means. In the context of Lacouture's retreat and the spiritual combat more generally, demons prey upon insecurities, constitutional weaknesses, and our ignorance in order to draw us back into our addiction to the natural world and sever our attachment to God. ${ }^{32}$ Moreover, they manifest in human form through les philosophes - morally bankrupt theological inquisitors, heretical preachers, and ecclesiastical authoritieswho are simultaneously victims and agents of demonic aggression. They will stop at nothing to interrupt the soul's attachment to God; thus, participating in the Lacouture retreat carried potentially grave consequences for the precise reason that it threatened the forces of evil. ${ }^{33}$ Even spiritual jealousy and competition for holiness (or a reputation for holiness) might well be the subtle

\footnotetext{
29 David Brakke, Demons and the Making of the Monk: Spiritual Combat in Early Christianity (Cambridge, MA: Harvard University Press, 2006), 10-11. Emphasis added.

$30 \quad$ Ibid., 241.

31 Lacouture, Mes retraites, 56 .

32 Ibid., 72.

33 Ibid., 85.
} 
tugs of demons attempting to sabotage God's work. ${ }^{34}$ Lacouture's sense of diabolic opportunism perceived psychological defects based on "progress," such as spiritual pride, to be a Trojan horse for demonic assault. ${ }^{35}$

Lacouture preached a rigid asceticism as part of a more comprehensive project of resuscitating traditional Canadien spirituality, which he saw being threatened by the then-ascendant social Catholicism that emerged as a sideeffect of early twentieth-century Québec's somewhat tardy entrance into the urban-industrial world. Lacouture's "doctrine" was self-consciously reactionary and virtually antisocial, with an uncompromising focus on the supreme dominion of God over against any and all interpersonal and socio-economic concerns. Although the retreat was never formally restricted to priests, they were certainly Lacouture's target audience in his vision of a kind of trickledown model of holiness. His mission was the rehabilitation of the clergy; to rescue them from the mediocrity that infected Canadian moral standards. Clerical corruption had precipitated a loss of the pious, agrarian lifestyle among native Québécois, and left the laity ill-equipped to resist the onslaught of Anglo-industrialist values.

Lacouture conceptualized his mission as a battle between Good and Evil. Characteristically, his deeply ingrained iconoclasm paired with an apocalyptic worldview both prompted him to theorize the notion that malevolent forces were afoot, as well as to entertain the idea that disapproving diocesan and Jesuit superiors were, in fact, demonic emissaries of Satan conspiring to undermine the opus Dei. This resulted in what he dubbed his "exile"; wherein he was forcibly silenced and circulated among western Jesuit provinces-Edmonton, then Santa Barbara, then Los Angeles. Although he managed to leak a few communiqués under the essentially unbelievable guise of private interpersonal correspondence, Lacouture's public ministry was effectively shut down by 1940 (although he continued to protest privately until his death in 1951). However, Lacouturisme had a colorful future south of the border, piloted by his charismatic devotee and arch-apologist, Fr. John J. Hugo.

\section{Lacouturisme's Southward Migration}

Throughout this time of increasing success there had been also increasing opposition. The devil could not tolerate such work as this! [...] The

34 Ibid., 125 .

35 Ignatius of Loyola, "Helpful Notes for the Perception and Understanding of Scruples and of the Insinuations of Our Enemy," in Personal Writings, trans. Joseph A. Munitiz and Philip Endean (New York: Penguin Books, 1996), 355-56. 
edifying conduct of all these priests on retreat, the edifying lives that they lived afterwards at their homes, were a reproach to many of the clergy. To the Jesuits also they were a reproach; not only because of the tepid among them, but also because the sensational success of this preacher, so plainly lacking in finish, was apt to cause questioning glances to be directed at their other more skillful teachers. ${ }^{36}$

Within the ranks of the Lacouturite disciples, Dorothy Day (1897-1980) stands out as one of the most enthusiastic and most famous. She is certainly the only one with an open cause for canonization in tow. Day first learned of the Lacouture retreat in the late 1930s and was subsequently introduced to its doctrinal substance by a Canadien Josephite priest named Pacifique Roy, who had himself become an avid student of Lacouture and great admirer of John Hugo. ${ }^{37}$ Roy was one of numerous unofficial pastors to the Catholic Worker, and suggested Hugo as the most gifted teacher of Lacouture's doctrine. It was not until the summer of 1941 that Day finally made the retreat under his supervision. Day's first experience of the retreat proved foundational, and she would later gush about it in her unfinished manuscript, All Is Grace:

I made this retreat [...] many times. The first time brought with it a shock of recognition that this was what I was looking for in the way of an explanation of the mystery of the Christian Life, the plan of God for us all. Though still I saw through a glass darkly, I saw things as a whole for the first time with a delight, a joy, an excitement, which is hard to describe. This is what I expected when I became a Catholic. This is what all my reading had led me to expect in the way of teaching and guidance in the spiritual life. I came away with what I can only consider to be an increased knowledge of the supernatural life, the feeling that I had grown in faith, hope and charity, that I had been fed the strong meat of the gospel and was now prepared to run the race, to journey onward with that food which would sustain me for forty days in any wilderness. I felt prepared for deserts and underground tunnels, for the dark night of the senses and of the soul. And I knew too that this strong light would dim with the ensuing months and that the next year I would again have to

36 John J. Hugo, Your Ways Are Not My Ways: The Radical Christianity of the Gospel, 2 vols. (Pittsburgh: Encounter with Silence, 1986), 1:197-98. 
make the retreat, to adjust my vision to the blazing truth which was set before us, to get things into perspective once again. ${ }^{38}$

The retreat served a rejuvenating function for Day, recommitting her to the supernatural life as an embodied protest against Christian mediocrity. As she testified, "For too long, too little has been expected of us."39 Although it unnerved Lacouture somewhat (there were limits to the synergy), Hugo's own activist orientation synced with Day's vision of the Catholic Worker's apostolate as a Christian witness grounded in what Day labeled "precarity" - a liminal form of existential poverty inspired by the Beatitudes and the Folly of the Cross. Day's absolute refusal to instrumentalize others in order to achieve practical ends, as well as her absolute pacifist stance, drew sharp criticism at times. However, the retreat's emphasis on detachment and its call to live on an elevated plane matched Day's own vision of prophetic Christianity and what she glibly referred to as the Worker's "poverty of reputation" - which rendered it, to a certain extent, unintelligible even to liberal Catholics whom Lacouturites believed were infected by the "pagan mentality."40

Lacouture's devoted students-perhaps John Hugo most of all-were electrified by his prophetic magnetism, and witnessed in Lacouture an alter Christus. To Hugo, Lacouture was the personification of the Gospel. From his very first retreat, Hugo's devotion to his Jesuit mentor was characterized by a pronounced and unflagging reverence that verged on fanaticism. ${ }^{41}$ Along with his new commitment to Lacouture's maximalist brand of Christianity came a biting critique of assimilationist "secularizing" Catholicism that possibly even superseded his mentor's. Hugo translated the retreat into American idioms, and almost single-handedly reconstituted what had been a primarily insular provincial clerical movement into a stimulant for radical spiritual renewal in the United States. Unlike Lacouture, Hugo tapped directly into the laitypreempting to the Second Vatican Council's articulation of "holiness for all." Hugo was a vigilant pugilist by nature, and was galvanized by his beloved teacher's suppression, which he interpreted in colorful, and typically Lacouture-ish

38 Day, All Is Grace (Dorothy Day-Catholic Worker Archives, Marquette University, [D-3:6]: undated fragments), 3 .

39 Day, "The Death of Father Onésime Lacouture, S.J.," The Catholic Worker (1951): 1 and 6, here 6.

40 Day, "Poverty and Precarity," The Catholic Worker (1952): 2-6, here 2 and 6.

41 Benjamin Peters, whose recently published book, Called to Be Saints, is the definitive treatment of Hugo to date, would likely disagree with the amplitude of this evaluation. Benjamin T. Peters, Called to Be Saints: John Hugo, the Catholic Worker, and A Theology of Radical Christianity (Milwaukee, wi: Marquette University Press, 2016). 
apocalyptic, cinematic terms-the Blitzkrieg, Inquisition, Holocaust, and Crucifixion were all points of comparison. ${ }^{42}$ Unlike Lacouture's surreptitious attempts to undermine the opposition, Hugo seemed happy enough to conduct his part of the controversy out in the open. Although he was temporarily forbidden from giving retreats, and was commissioned to a series of parish posts in Pittsburgh suburbs, it was just a brief time before Hugo had his full clerical faculties reinstated.

Lacouturisme offered a rugged, confrontational spirituality that was uncompromising and exacting in its determination to cede precious little ground in its demands for holiness. Day shared these characteristics - which were no small part of her magnetic appeal—with Lacouture and Hugo. However, they also made her vulnerable to charges of hyper-scrupulosity, elitism, and lack of charity. ${ }^{43}$ As Québécois Lacouturisme had represented a dissenting position against Catholic assimilation into secular culture, Day's permutation often defined itself against the normative Church as the "Cross on which Christ was crucified."44 Although Lacouture himself would likely have been sympathetic to Day's romantic neo-agrarianism, the Catholic Worker's anarchist agitation was a synthetic innovation that inculturated Lacouturisme into Day's alreadyformed political radicalism and communitarian sensibilities that predated even her conversion to Roman Catholicism in 1927.45

Day's conception of the spiritual combat demanded that the interior resources collected during the days of silence on retreat be expressed in resistance, as a Catholic Left "theology of the streets." ${ }^{46}$ The anti-triumphalist theology that the Catholic Worker developed under Day's stewardship, based on a proto-liberationist sacramental vision of suffering, was diametrically opposed to the scandals of us imperialism abroad, labor exploitation, and poverty. Other Catholic Workers found it too uncompromising, and resented the retreat's "joyless" asceticism. ${ }^{47}$ Some critics contend that Lacouturisme was,

42 John J. Hugo, Applied Christianity (New York: n.p., 1944).

43 Peters's Called to Be Saints provides a meticulous and helpful historiography of scholarship on Hugo, 15-51. It is worth noting what is perhaps a distinction between historical theological and religious studies approaches here- insofar as Day historians who fall more nicely within the former camp seem to be at pains to exonerate her of Jansenist charges, whereas religious studies historians attend less to questions of formal orthodoxy. A favorite quote of Day's, by Romano Guardini, in Robert Coles, Dorothy Day: A Radical Devotion (Reading, MA: Addison-Wesley Publishing Company, 1987), 66.

45 Peters, Called to Be Saints, 171-73.

46 Robert A. Orsi, The Madonna of $115^{\text {th }}$ Street: Faith and Community in Italian Harlem, 18801950 (New Haven, Ст: Yale University Press, 1985), $219 f f$.

47 Kate Hennessy, Dorothy Day: The World Will Be Saved by Beauty (New York: Simon \& Schuster, 2017), 126. 
at its roots, theologically toxic while others have suggested that it was simply Hugo's adaptation that radicalized the retreat's more severe elements. ${ }^{48}$

\section{In Memoriam}

Onésime Lacouture's ethic of non-participation shared in the Worker's extreme praxis of interior mortification, but contrasted sharply with its commitment to radical civic engagement. Lacouture's sojourn in the Alaskan "White Desert" precipitated a radical conversion towards a rugged Christianity, setting holiness as a standard rather than a remote ideal. Lacouture's congenital inability to make nice with his critics, coupled with his apparent allergy to obedience and discretion, created a combustible cocktail that virtually guaranteed his suppression just as he gained influence among young Canadien seminarians and clergy. However, he managed to convert a core group of enthusiastic disciples, including some remarkable pilgrims from south of the border who imported Lacouturisme into the United States and adapted it to different cultural idioms, while also struggling to maintain the program's essential pith. Their unrelentingly deocentric vision of ordered affect and moral purity was pegged to their teacher's enthusiastic, politically reclusive supernaturalism, but also bore a radical imperative towards social transformation.

From the perspective of the "pagan mentality" and spiritual pragmatism that dictate moral norms among even observant Christians, the Lacouturite doctrines of self-mortification and opposition to "the world" was scandalous, theologically dubious, and downright seditious. However, for the legion of Lacouturite faithful, it truly was - and, for a small community of contemporary Lacouturites, remains - a siren call to recollect Christian fundamentals amidst tidal waves of apathy and apostasy. Following Lacouture's death in 1951, Dorothy Day made a pilgrimage to Upstate New York for his funeral to pay her last respects, and eulogize one of her greatest spiritual fathers-second only to Catholic Worker co-founder Peter Maurin in terms of influence. Returning to Manhattan, she tasked herself with reflecting on the measure of Lacouture's life work and legacy in the pages of the Catholic Worker:

I could write a great deal about that retreat, and all it brought to us, the new vistas which opened out before us. But I will simply say that it gave us spiritual direction. We were learning how to die to ourselves, to live in Christ, and all the turmoil of the movement, all the pruning of natural love, all the disappointments were explained by the doctrine of the Cross,

48 See J. Leon Hooper, S.J., "Murray and Day: A Common Enemy, a Common Cause?" U.s. Catholic Historian 24, no. 1 (2006): 45-61; Hennessy, Dorothy Day, 126-26; Stanley Vishnewski, Wings of the Dawn (New York: Catholic Worker Press, 1984), 209-12. 
in the folly of the Cross. The retreat gave us hope and courage, as retreats are supposed to do, and we will be everlastingly grateful for it, grateful to Fr. Lacouture, who made the retreat possible for us. We feel that we have been participants in a great spiritual movement which is still going on, though it is perhaps now in shadow. The seed has fallen to the ground and has died. But we know that it will bear great fruit. ${ }^{49}$

49 Dorothy Day, "Death of Father Onesimus Lacouture, S.J.," 6. 